\title{
KOMPETENSI PEDAGOGIK TUTOR DALAM MENINGKATKAN MOTIVASI BELAJAR WARGA BELAJAR PKBM CITATAH ENDAH BANDUNG BARAT
}

\author{
${ }^{1}$ Wawan Hardiyanto, ${ }^{2}$ Babang Robandi \\ ${ }^{1}$ Akademi Kesekretariatan, Akademi Sekretaris dan Manajemen Kencana Bandung, \\ ${ }^{2}$ Pendidikan Guru Sekolah Dasar FIP Universitas Pendidikan Indonesia \\ wawanhardiyanto@asmkencana.ac.id, brobandi@upi.edu
}

\begin{abstract}
ABSTRAK
Penelitian ini bertujuan untuk mengetahui sejauh mana kompetensi pedagogik tutor PKBM Citatah Endah dalam meningkatkan motivasi belajar warga belajarnya. Pendekatan penelitian yang digunakan adalah pendekatan kualitatif, di mana data yang diperoleh berasal dari wawancara dengan narasumber, observasi dan kajian dokumentasi. Sementara yang menjadi subjek penelitian adalah Kepala PKBM, tutor PKBM dan para warga belajar. Hasil penelitian menunjukkan bahwa: (1) Kompetensi pedagogik tutor dalam perencanaan pembelajaran dilakukan dengan membuat draft RPP, namun sebagian tutor tidak membawa RPP pada saat proses belajar mengajar berlangsung sehingga tujuan pembelajaran tidak tercapai secara maksimal; (2) Kompetensi pedagogik tutor dalam proses pembelajaran dilakukan dengan mendalami dan memantapkan sejumlah materi pembelajaran sebagaimana terdapat dalam buku paket, adapun dalam proses pembelajaran terdapat pengelolaan kelas yang kurang baik dan pemanfaatan waktu yang kurang disiplin; dan (3) Kompetensi pedagogik tutor dalam meningkatkan motivasi belajar warga belajar dilakukan dengan memberi kesempatan kepada warga belajar untuk terlibat aktif dalam menggunakan fasilitas teknologi informasi dan komunikasi dalam pencapaian tujuan pembelajaran, berkomunikasi secara efektif dengan warga belajar, dan melakukan tindakan reflektif untuk peningkatan kualitas pembelajaran.
\end{abstract}

Kata kunci: Kompetensi Pedagogik, Motivasi Belajar, PKBM

\begin{abstract}
This study aims to know more about the paedagogical competence of the tutors of the PKBM Citatah Endah in increasing the learning motivation of the students. The study used the qualitative approach, which the data is collected by the interview with the sources, observation, and documentation study. Meanwhile, the subjects of the study are the headmaster of the PKBM, the tutors, and the students. The results of the study shows that: (1) The paedagogical competence of the tutors is started by preparing the learning-plans in the frame of RPP drafts, but some of them do not bring them when the process of learning is conducted, so the goals of the learning process were not achieved maximally; (2) The paedagogical competence of the tutors in the learning-process is done by enriching the materials comprehensively as served in the manual books, but there were still many problems in the classmanagement and time-management; and (3) The paedagogical competence of the tutors in the frame of increasing the students' motivation is conducted by giving a chance to the students to involve in the learning-process actively, especially in using the information-communication technology to achieve the goals, and the tutors communicate with the students effectively and doing the reflective-process to increase the quality of the learning-process.
\end{abstract}

Keywords: Paedagogical Competence, Learning Motivation, PKBM 


\section{PENDAHULUAN}

Dewasa ini banyak sekali tantangan yang dihadapi oleh dunia pendidikan, hasil akhir yang diperoleh oleh peserta didik belum mampu memberikan senyuman yang membuat harum nama bangsa Indonesia, kualitas belajar mengajar patut dipertanyakan dan motivasi belajar peserta didik masih sangat rendah. Hal ini harus diperbaiki untuk hasil yang lebih baik dalam proses belajar mengajar. Adapun proses belajar merupakan aktivitas belajar aktif dalam merangkai pengalaman, menggunakan masalah nyata yang terdapat di lingkungannya. Belajar tidaklah bersifat pasif, belajar merupakan proses aktif dalam memperoleh pengalaman pengetahuan dan informasi baru. Setelah belajar seseorang memiliki keterampilan, kemampuan, sikap, dan nilai. Dalam hal ini Sagala (2012) menyatakan bahwa belajar dipahami sebagai berusaha atau berlatih supaya mendapat sesuatu kepandaian. Dalam implementasinya belajar adalah kegiatan individu memperoleh pengetahuan perilaku dan keterampilan dengan cara mengolah bahan belajar.

Berdasarkan pernyataan di atas, dapat dipahami bahwa kegiatan belajar membutuhkan latihan dan latihan dapat menimbulkan pengalaman, dengan pengalaman itulah seseorang dapat terlatih dalam mewujudkan suatu keterampilan yang bersifat khusus. Untuk merangkai pengalaman belajar yang sempurna hendaknya dalam proses belajar mengajar melibatkan fungsi dan kegunaan metode pembelajaran, media pembelajaran, teknik evaluasi, karakteristik wilayah/daerah, karakteristik siswa, kepedulian orang tua, motivasi siswa, kesempatan dan peluang mengajar guru, dan lain sebagainya.

Dewasa ini telah banyak pendekatan yang dikembangkan oleh para ahli, baik dengan sasaran anak-anak maupun orang dewasa. Masing-masing pendekatan tentunya memiliki kelebihan dan kekurangan, karena tidak ada sesuatu yang sempurna di dunia ini termasuk pendekatan yang digunakan oleh pendidik dalam pembelajarannya. Pendekatan yang dimaksud disini adalah pedagogik.

Proses pembelajaran yang melibatkan siswa secara langsung dalam kegiatan belajar mengajar dapat menciptakan kerjasama dengan siswa lain dan dapat memperoleh informasi yang banyak. Hamalik (2012), menyatakan bahwa pembelajaran merupakan kombinasi yang tersusun meliputi unsur-unsur manusiawi, material, fasilitas, perlengkapan, dan prosedur yang saling mempengaruhi mencapai tujuan pembelajaran.

Oleh karena itu, kemampuan pemahaman tentang peserta didik secara mendalam dan penyelenggaraan pembelajaran meliputi pemahaman tentang psikologi perkembangan anak, kesehatan anak, lingkungan sosial dan kemampuan orang tua murid merupakan siklus pemahaman yang harus dipahami guru dalam meningkatkan kompetensi pedagogiknya dalam proses belajar mengajar.

\section{KAJIAN TEORI}

\section{Pengertian Pedagogi}

Pedagogi berasal dari bahasa Yunani paedagogeo, dimana terdiri dari paidos dan genetif, paidos yang berarti anak dan agogo yang berarti memimpin, sehingga secara harfiah pedagogi, berarti memimpin anak. Dalam bahasa Yunani kuno, kata pedagogi bermakna seorang budak (pengawas rumah tangga) yang mengawasi pengajaran putra tuannya atau majikannya, ketika itu anak perempuan tidak diberi pengajaran khusus, pembantu rumah tangga ini mengantar, 
menunggu dan menemani pulang putra tuannya ke pada saat dan dari sekolah atau gymnasium. Kata pedagogi juga diturunkan dari Bahasa Latin yang bermakna mengajari anak, sementara dalam Bahasa Inggris istilah pedagogi (pedagogy) digunakan untuk merujuk kepada teori pengajaran, dimana guru berusaha memahami bahan ajar, mengenal siswa dan menentukkan cara mengajarnya.

Menurut Sudarwan Danim (2010), ada tiga isu terkait dengan penggunaan istilah pedagogi, yakni (1) pedagogi merupakan sebuah proses yang bertujuan, dalam makna umum istilah pedagogik digunakan untuk menjelaskan prinsip-prinsip dan praktik mengajar anak-anak, (2) banyak pekerjaan "pedagogi sosial" yang telah digunakan untuk menggambarkan prinsipprinsip mengajar anak-anak dan kaum muda, dan (3) pengertian pedagogi telah dipahami dan dominan mewarnai proses pembelajaran dalam konteks sekolah. Secara tradisional istilah pedagogi adalah seni mengajar. Sementara dilihat dari pedagogi modern, dilihat dari hubungan dialektis yang bermanfaat antara pedagogi sebagai ilmu dan pedagogi sebagai seni.

Beberapa definisi yang terkait pengertian pedagogi sebagai ilmu dan seni menurut Sudarwan Danim (2010) antara lain:

1) Pengajaran (teaching) yaitu teknik dan metode kerja guru dalam mentranformasikan konten pengetahuan, merangsang mengawasi dan menfasilitasi pengembangan siswa untuk mencapai tujuan pembelajaran, pengertian ini menempatkan guru pada posisi sentral;

2) Belajar (learning) yaitu proses siswa mengembangkan kemandirian dan inisiatif dalam memperoleh dan meningkatkan pengetahuan serta keterampilan;

3) Hubungan mengajar dengan belajar dengan segala faktor lain yang ikut mendorong minat pedagogi. Hubungan ini bisa bermakna siswa dibimbing guru atau kegiatan belajar yang berpusat pada siswa, namun tetap dibawah bimbingan guru;

4) Hubungan mengajar dan belajar berkaitan dengan semua pengaturan dan pada segala tahapan usia, sebagaimana dikembangkan di lembaga pendidikan formal dan nonformal. Sekolah merupakan salah satu bagian dari total spektrum pengaruh pendidikan.

Dengan demikian, pedagogi yang efektif mencoba menggabungkan alternatif strategi pembelajaran yang mendukung keterlibatan intelektual, memiliki keterhubungan dengan dunia yang lebih luas, lingkungan kelas yang koduksif dan pengakuan atas perbedaan penerapan pada semua pelajaran.

\section{Pengertian Kompetensi Pedagogik}

Dilihat dari segi proses pembelajaran, kompetensi pedagogik merupakan kemampuan guru dalam pengelolaan pembelajaran peserta didik. Hal ini harus mampu diwujudkan oleh setiap guru untuk mencerdaskan kehidupan bangsa. Lebih lanjut, dalam standar nasional pendidikan, penjelasan pasal 28 ayat (3) butir (a) dikemukakan bahwa yang dimaksud dengan kompetensi pedagogik adalah kemampuan mengelola pembelajaran peserta didik meliputi pemahaman terhadap peserta didik, perancangan dan pelaksanaan pembelajaran, evaluasi hasil belajar, dan pengembangan peserta didik untuk mengaktualisasi ragam potensi yang dimilikinya.

Kondisi ini, dalam tinjauan Mulyasa (2009), sekurang-kurangnya meliputi aspek-aspek berikut, yaitu: (a) pemahaman wawasan dan landasan kependidikan, (b) pemahaman terhadap peserta didik, (c) pengembangan kurikulum/silabus, (d) perancangan pembelajaran, (e) pelaksanaan pembelajaran yang mendidik dan dialogis, (f) pemanfaatan teknologi 
pembelajaran, (g) evaluasi hasil belajar (EHB), dan (h) pengembangan peserta didik untuk mengaktualisasikan berbagai potensi yang dimilikinya.

\section{Tugas dan Tanggungjawab Guru dalam Pengembangan Profesi}

Seorang guru yang profesional adalah orang yang memiliki kemampuan dan keahlian dalam bidang keguruan atau dengan kata lain ia telah terdidik dan terlatih dengan baik. Pemahaman terdidik dan terlatih adalah menguasai berbagai strategi atau teknik dalam kegiatan belajar mengajar serta menguasai landasan-landasan kependidikan sebagaimana yang tercantum dalam kompetensi guru. Dalam situasi sekarang tugas dan tanggung jawab guru dalam pengembangan profesi nampaknya belum banyak dilakukan. Yang paling menonjol hanyalah tugas dan tanggungjawab sebagai pengajar dan administrator kelas. Dalam hubungan ini Sudjana (2011) menyatakan bahwa pada dasarnya kompetensi guru bertugas sebagai pengajar, pembimbing, maupun sebagai administrator kelas.

Untuk keperluan analisis tugas guru sebagai pengajar, maka kemampuan guru atau kompetensi guru yang banyak hubungannya dengan usaha meningkatkan proses dan hasil belajar dapat diguguskan ke dalam empat kemampuan yakni: (a) merencanakan program mengajar, (b) melaksanakan dan memimpin/mengelola proses belajar mengajar, (c) menilai kemajuan proses belajar mengajar, dan (d) menguasai bahan pelajaran dalam pengertian menguasai bidang studi atau mata pelajaran yang diajarinya.

Keempat kemampuan ini merupakan kemampuan yang sepenuhnya harus dikuasai guru yang bertaraf profesional. Berdasarkan uraian di atas, konsep kompetensi guru dapat diartikan sebagai kemampuan dasar melaksanakan tugas keguruan yang dapat dilihat dari kemampuan merencanakan pembelajaran, kemampuan melaksanakan atau mengelola proses belajarmengajar, dan kemampuan menilai proses belajar mengajar.

\section{Motivasi Belajar Peserta Didik}

Banyak para ahli yang sudah mengungkapkan pengertian motivasi dengan berbagai sudut pandang mereka masing-masing, namun intinya sama, yakni sebagai suatu pendorong yang mengubah energi dalam diri seseorang ke dalam bentuk aktivitas nyata untuk mencapai tujuan tertentu. Dalam proses belajar, motivasi sangat diperlukan, sebab seseorang yang tidak mempunyai motivasi dalam belajar, tak akan mungkin melakukan aktivitas belajar. Hal ini merupakan pertanda bahwa seseorang yang akan dikerjakan itu tidak menyentuh kebutuhannya. Segala sesuatu yang menarik minat orang lain belum tentu menarik minat orang tertentu selama sesuatu itu tidak bersentuhan dengan kebutuhannya.

Maslow (Uno, 2008) menyebutkan bahwa kebutuhan manusia secara hierarkis semuanya laten dalam diri manusia. Kebutuhan tersebut mencakup kebutuhan fisiologis (sandang pangan), kebutuhan rasa aman (bebas bahaya), kebutuhan kasih sayang, kebutuhan dihargai dan dihormati, dan kebutuhan aktualisasi diri. Aktualisasi diri, penghargaan atau penghormatan, rasa memiliki, dan rasa cinta atau sayang, perasaan aman, dan tenteram merupakan kebutuhan fisiologis mendasar. Kebutuhan-kebutuhan inilah menurut Maslow yang mampu memotivasi tingkah laku individu. Oleh karena itu, apa yang seseorang lihat sudah tentu akan membangkitkan mintanya sejauh apa yang ia lihat itu mempunyai hubungan dengan kepentingannya sendiri. 
Hamalik (Djamarah, 2011), menyebutkan bahwa motivasi adalah suatu perubahan energi di dalam pribadi seseorang yang ditandai dengan timbulknya afektif (perasaan) dan reaksi untuk mencapai tujuan. Perubahan energi dalam diri seseorang itu berbentuk aktivitas nyata berupa kegiatan fisik, karena seseorang memiliki tujuan tertentu dari aktivitasnya, maka seseorang memiliki motivasi yang kuat untuk mencapainya dengan segala upaya yang dapat dia lakukan untuk mencapainya.

Uno (2008) menjelaskan bahwa motivasi berasal dari kata motif yang dapat diartikan sebagai kekuatan yang terdapat dalam diri individu, yang menyebabkan individu tersebut bertindak atau berbuat. Motif tidak dapat diamati secara langsung, tetapi dapat diinterpretasikan dalam tingkah lakunya, berupa rangsangan, dorongan, atau pembangkit tenaga munculnya suatu tingkah laku tertentu.

Motif dapat dibedakan menjadi tiga macam, yaitu: (a) motif biogenetis, yaitu motif-motif yang berasal dari kebutuhan kebutuhan organisme dei kelanjutan hidupnya, misalnya haus, lapar, kebutuhan akan kegiatan dan istirahat, mengambil napas, seksualitas, dan sebagainya, (b) motif sosio-genetis, yaitu motif-motif yang berkembang berasal dari lingkungan kebudayaan tempat orang tersebut berada. Jadi, motif ini tidak berkembang dengan sendirinya, tetapi dipengaruhi oleh lingkungan kebudayaan setempat. Misalnya keinginan mendegarkan musik, makan pecal, makan cokelat, dan lain-lain, dan (c) motif teologis, dalam motif ini manusia adalah sebagai makhluk yang berketuhanan, sehingga ada interaksi antara manusia dengan Tuhan-Nya, seperti ibadahnya dalam kehidupan sehari-hari, misalnya keinginan untuk mengabdi kepada Tuhan Yang Maha Esa untuk merealisasikan norma-norma sesuai agamanya.

Dari uraian di atas, dapat dipahami bahwa motivasi adalah serangkaian usaha untuk menyediakan kondisi-kondisi tertentu, sehingga seseorang mau dan ingin melakukan sesuatu atau suatu energi penggerak dan pengarah yang dapat memperkuat dan mendorong seseorang untuk bertingkah laku. Dengan demikian, setiap perbuatan seseorang tergantung pada motivasi yang mendasarinya, karena motivasi merupakan sesuatu yang dibutuhkan untuk melakukan aktivitas.

Dari beberapa pendapat di atas, dapat disimpulkan bahwa motivasi adalah keseluruhan daya penggerak baik dari dalam diri maupun dari luar dengan menciptakan serangkaian usaha untuk menyediakan kondisi-kondisi tertentu yang menjamin kelangsungan dan memberikan arah pada kegiatan sehingga tujuan yang dikehendaki oleh subjek itu dapat tercapai. Perubahan energi dalam diri seseorang itu berbentuk suatu aktivitas nyata berupa kegiatan fisik. Karena seseorang mempunyai tujuan tertentu dari aktivitasnya, maka seseorang mempunyai motivasi yang kuat untuk mencapainya dengan segala upaya yang dapat dia lakukan untuk mencapainya.

Seseorang yang melakukan aktivitas belajar secara kontinue tanpa motivasi dari luar dirinya merupakan motivasi intrinsik yang sangat penting dalam aktivitas belajar. Namun seseorang yang mempunyai keinginan untuk belajar, dorongan dari luarnya merupakan motivasi intrinsik yang diharapkan. Oleh karena itu, motivasi intrinsik diperlukan bila motivasi intrinsik tidak ada dalam diri seseorang sebagai subjek belajar.

Secara umum motivasi itu dapat dibagi dalam dua bentuk yaitu motivasi intrinsik yaitu motif-motif yang menjadi aktif atau berfungsinya tidak perlu diransang dari luar, karena dalam setiap individu sudah ada dorongan untuk melakukan sesuatu dan motivasi ekstrinsik yaitu motif-motif yang aktif dan berfungsi karena adanya stimulasi dari luar, tentunya motivasi 
ekstrinsik ini merupakan kebalikan dari motivasi instrinsik sebagaimana yang penulis jelaskan di atas.

Motivasi dan peran guru sebagai pendidik merupakan peran dan fungsi yang berkaitan dengan tugas-tugas dalam memberi bantuan dan dorongan (support), tugas-tugas pengawasan dan pembinaan (supervisor) serta tugas-tugas yang berkaitan dengan mendisiplinkan anak agar anak patuh terhadap aturan-aturan sekolah dan norma hidup dalam keluarga dan masyarakat. Tugas-tugas ini berkaitan dengan meningkatkan pertumbuhan dan perkembangan anak.

Oleh karena itu, pendidikan harus berusaha menimbulkan motif intrinsik dengan menumbuhkan dan mengembangkan minat peserta didik terhadap jenis bidang studi yang relevan. Sebagai contoh, memberitahukan sasaran yang hendak dicapai dalam bentuk tujuan instruksional pada saat pembelajaran akan dimulai yang menimbulkan motif keberhasilan mencapai sasaran.

Selanjutnya untuk menumbuhkan motif ekstrinsik, dalam tinjauan Uno (2008), ada beberapa persiapan yang dapat dilakukan oleh seorang guru, yaitu: (a) pendidik memerlukan anak didiknya sebagai manusia yang berpribadi, menghargai pendapatnya, pikirannya, perasaannya, maupun keyakinannya, (b) pendidikan menggunakan berbagai metode dalam melaksanakan kegiatan pendidikannya, (c) pendidik senantiasa memberikan bimbingan dan pengarahan kepada anak didiknya dan membantu apabila mengalami kesulitan, baik yang bersifat pribadi maupun akademik, (d) pendidik harus mempunyai pengetahuan yang luas dan penguasaan bidang studi atau materi yang diajarkan kepada peserta didiknya, dan (e) pendidik harus mempunyai rasa cinta dan sifat pengabdian kepada profesinya sebagai pendidik. Semua ciri di atas harus dimiliki oleh pendidik dalam upaya memberikan motivasi kepada peserta didiknya dan mengabdi kepada profesinya sebagai pendidik.

Berdasarkan pengertian di atas, maka tiga standar keunggulan tersebut merupakan prinsip dasar untuk memeriksa adanya motivasi. Oleh karena itu, dapat disimpulkan bahwa motivasi dalam tinjauan ini adalah suatu dorongan yang menuntut individu berusaha lebih keras untuk mencapai tujuan yang diinginkan.

\section{Pengertian Pusat Kegiatan Belajar Masyarakat (PKBM)}

PKBM adalah singkatan dari Pusat Kegiatan Belajar Masyarakat merupakan sebuah lembaga yang dibentuk oleh masyarakat untuk masyarakat yang bergerak dalam bidang pendidikan. PKBM bisa diselenggarakan di tingkat desa/kelurahan ataupun tingkat kecamatan, atau oleh siapapun yang memenuhi persyaratan kelembagaan, seperti: Akta Notaris, NPWP, Susunan Kepengurusan, Sekretariat, dan Izin Operasional dari Dinas Pendidikan Kabupaten/Kota setempat.

Cakupan kegiatan PKBM meliputi: Kejar Paket (A, B, C), Pendidikan Anak Usia Dini, Kelompok Belajar Usaha, Kelompok Usaha Pemuda Produktif, Pemberdayaan Perempuan, Keaksaraan Fungsional Dasar Dewasa, dan Taman Bacaan Masyarakat. (wikipedia.org/wiki/PKBM). Sementara menurut UNESCO, PKBM adalah lembaga pusat kegiatan belajar masyarakat yang diselenggarakan di luar sistem pendidikan formal yang diarahkan untuk masyarakat pedesaan dan perkotaan dengan dikelola oleh masyarakat itu sendiri serta memberi kesempatan kepada mereka untuk mengembangkan berbagai model pembelajaran dengan tujuan untuk mengembangkan kemampuan dan keterampilan masyarakat agar mampu meningkatkan kualitas hidupnya. (Mustafa Kamil, 2009). Sedangkan 
Kementerian Pendidikan dan Kebudayaan menyebut PKBM sebagai satuan pendidikan nonformal tempat pembelajaran dan sumber informasi yang dibentuk dan dikelola oleh masyarakat yang berorientasi pada pemberdayaan potensi setempat untuk meningkatkan pengetahuan, keterampilan dan sikap masyarakat dalam bidang ekonomi, sosial dan budaya.

\section{Spektrum PKBM}

Ketika pendidikan nonformal dijadikan sebagai sebuah strategi dalam pengembangan dan pembangunan masyarakat, maka PKBM tampil sebagai salah satu wadah dalam mewujudkan program-program pendidikan dan keterampilan yang terpadu dengan kehidupan dan kebutuhan masyarakat.

\section{Program Pendidikan Kesetaraan Paket C di PKBM}

PKBM memiliki posisi yang strategis dalam penyelenggaraan program pendidikan non formal atau dulu dikenal dengan pendidikan luar sekolah. Hal ini ditunjukkan pada Undangundang Nomor 20 Tahun 2003 tentang Sistem Pendidikan Nasional yang menetapkan PKBM sebagai salah satu satuan pendidikan non formal. Kejar Paket C merupakan salah satu PKBM pendidikan berjenjang setara SMA. Program ini dikembangkan mengingat banyaknya warga masyarakat lulusan Paket B dan SMP yang tidak melanjutkan, serta putus sekolah SMA/ MA, dan usia produktif yang ingin mengembangkan diri dalam kecakapan hidup sehingga perlu diadakan pola pelayanan yang dapat memberikan kepada mereka untuk siap memasuki dunia kerja atau melanjutkan ke jenjang yang lebih tinggi.

Namun keberhasilan suatu PKBM baik secara kualitas maupun kuantitas sangat ditentukan oleh baik tidaknya tenaga (tutor) yang menangani warga belajar dalam proses pembelajaran. Tutor sebagai ujung tombak pembelajaran sangat berpengaruh dalam menentukan mutu hasil belajar di PKBM. Untuk itu dalam peningkatan mutu hasil belajar diperlukan suatu manajemen pembelajaran yang baik.

\section{METODOLOGI}

Berlandaskan kepada pokok permasalahan yang dibahas dalam tulisan ini, yaitu Kompetensi Pedagogik Tutor Dalam Meningkatkan Motivasi Belajar Warga Belajar PKBM Citatah Endah Kecamatan Cipatat Kabupaten Bandung Barat, maka penelitian ini menggunakan metode deskriptif kualitatif.

Metode deskriptif kualitatif dapat diartikan sebagai prosedur pemecahan masalah yang diselidiki dengan menggambarkan atau melukiskan keadaan subjek atau objek penelitian (orang, lembaga dan masyarakat) pada saat sekarang berdasarkan fakta-fakta yang nampak dan sebagaimana adanya (Nawawi, 2005).

Lokasi penelitian ini dilakukan di Pusat Kegiatan Belajar Masyarakat (PKBM) Citatah Endah yang beralamat di Kampung Cicocok RT.03 RW.03 Desa Citatah Kecamatan Cipatat Kabupaten Bandung Barat. Lokasi ini dipilih dengan mempertimbangkan beberapa alasan, diantaranya adalah bahwa PKBM Citatah Endah berada pada daerah yang strategis, di mana terdapat banyak lokasi pariwisata, pendidikan militer serta penambangan dan selama lima belas tahun terakhir ini PKBM Citatah Endah secara konsisten memberikan pelayanan program pendidikan kesetaraan kepada masyarakat. 
Disamping alasan tersebut, alasan lainnya yang membuat peneliti memilih lokasi penelitian di PKBM Citatah Endah adalah memiliki struktur dan tata kelola organisasi yang baik sehingga mendapatkan legalitas Nomor Pokok Sekolah Nasional (NPSN) P.2964359 dari Departemen Pendidikan Nasional. Selain itu, juga sudah memiliki gedung sendiri yang memudahkan masyarakat untuk mencari ilmu, sehingga mendapat kepercayaan dari masyarakat. Jumlah lulusan Paket C tahun 2019/2020 saja 280 orang, dengan latar belakang warga belajar yang beragam. Melihat keunggulan tersebut, maka terlihat sekali bahwa motivasi belajar bagi warga belajar program pendidikan kesetaraan Paket C di PKBM Citatah Endah tersebut sangat penting ditingkatkan baik secara kuantitas maupun kualitasnya, terutama bagi yang memiliki motivasi belajar yang tinggi.

Pada penelitian ini, subyek penelitian adalah kompetensi pedagogik tutor dalam meningkatkan motivasi belajar warga belajar program pendidikan kesetaraan Paket C di Pusat Kegiatan Belajar Masyarakat terdiri dari 20 responden, yaitu 12 subyek primer warga belajar Paket A, B. dan C yang biasa disebut dengan penerima manfaat dan 8 subyek primer sekaligus subyek sekunder (pengelola dan tutor) yaitu 1 orang kepala PKBM dan 7 tutor.

Untuk membuktikan keabsahan data dalam penelitian ini hanya digunakan triangulasi sumber, hal ini dilakukan agar data yang disajikan sebagai hasil penelitian nanti benar-benar objektif. Keabsahan data dilakukan peneliti dengan cara membandingkan hasil wawancara yang diperoleh dari pertanyaan-pertanyaan yang diajukan kepada tutor, dilanjutkan kepada warga belajar. Peneliti membandingkan hasil wawancara tutor Paket Kesetaraan dengan isi suatu dokumen yang berkaitan dengan macam-macam mata pelajaran yang ada di PKBM Citatah Endah.

\section{HASIL PENELITIAN DAN PEMBAHASAN}

\section{Hasil Penelitian}

Hasil penelitian membuktikan bahwa kompetensi pedagogik tutor dalam perencanaan pembelajaran di PKBM Citatah Endah berpedoman pada kurikulum dan silabus. Dalam perencanaan pembelajaran tersebut memuat analisis materi pembelajaran yang di dalamnya memuat tentang standar kompetensi, kompetensi dasar, indikator dan materi pokok. Dengan adanya acuan terhadap rencana pembelajaran diyakini bahwa pembelajaran yang diajarkan guru akan lebih terarah, berkesinambungan, dan lebih fleksibel.

Hal ini sesuai dengan pernyataan Harun (2010) yang mengatakan bahwa perencanaan pengajaran akan berhasil dilakukan apabila mencakup tujuh kategori, yaitu: (a) perencanaan berdasarkan tujuan yang jelas, (b) adanya kesatuan rencana, (c) logis, (d) kontinuitas, (e) sederhana dan jelas, (f) fleksibel, dan (g) stabilitas. Sebagaimana yang telah penulis kemukakan sebelumnya perencanaan merupakan salah satu fungsi awal dari aktivitas manajemen, dalam proses penetapan dan pemanfaatan sumber daya secara terpadu yang diharapkan dapat menunjang kegiatan-kegiatan dan upaya-upaya yang dilaksanakan secara efisien dan efektif dalam mencapai tujuan.

Berkaitan dengan perencanaan pembelajaran yang menjadi tanggungjawab tutor dalam proses belajar mengajar, terdapat beberapa cara yang berkaitan dengan perencanaan bahan pelajaran di antaranya guru harus melengkapinya dengan program tahunan, program semester, silabus, RPP, kriteria ketuntasan minimal, daftar hadir siswa dan buku nilai. Bagi tutor, 
perencanaan yang terpenting adalah perencanaan unit, perencanaan mingguan dan perencanaan harian.

Oleh karena itu, perencanaan pembelajaran pada tingkat satuan pendidikan merupakan persiapan yang harus dilaksanakann oleh tutor sebagai langkah awal dalam suatu proses kegiatan belajar mengajar. Dalam pelaksanaannya, langkah awal yang harus dilaksanakan oleh seorang tutor adalah penelaahan kurikulum yang dikembangkan dalam bentuk silabus. Selanjutnya dikembangkan menjadi proses belajar mengajar yang aktif, kreatif, inovatif dan menyenangkan. Perencanaan yang baik akan memberikan dampak yang baik juga terhadap proses belajar mengajar.

Perencanaan pembelajaran merupakan persiapan yang harus dilaksanakan oleh tutor dan merupakan langkah awal dari suatu kegiatan pembelajaran. Hasil penelitian lainnya membuktikan bahwa kompetensi pedagogik tutor dalam proses pembelajaran di PKBM Citatah Endah dapat diamati melalui beberapa aspek yaitu:

\section{a) Menguasai teori belajar dan prinsip-prinsip pembelajaran yang mendidik}

Hasil penelitian membuktikan bahwa kompetensi pedagogik tutor dalam proses pembelajaran di PKBM Citatah Endah ditinjau dari aspek penguasaan teori belajar dan prinsipprinsip pembelajaran yang mendidik dilakukan dengan cara mendalami masing-masing materi pembelajaran secara konseptual melalui bacaan buku-buku dan literatur tentang disiplin ilmu masing-masing.

\section{b) Mengembangkan kurikulum yang terkait dengan mata pelajaran yang diampu}

Hasil penelitian membuktikan bahwa kompetensi pedagogik tutor dalam proses pembelajaran di PKBM Citatah Endah ditinjau dari aspek pengembangan kurikulum yang terkait dengan mata pelajaran yang diampu dilakukan dengan memantapkan sejumlah materi pembelajaran kepada warga belajar secara baik dan benar dan sesuai alokasi waktu pembelajaran yang disediakan.

c) Memfasilitasi pengembangan potensi peserta didik untuk mengaktualisasikan berbagai potensi yang dimiliki

Hasil penelitian membuktikan bahwa kompetensi pedagogik tutor dalam proses pembelajaran di PKBM Citatah Endah ditinjau dari aspek pengembangan potensi peserta didik untuk mengaktualisasikan berbagai potensi yang dimiliki dilakukan dengan memberikan sejumlah latihan dalam bentuk pekerjaan rumah yang berhubungan dengan materi pembelajaran yang sudah diajarkan.

\section{d) Memanfaatkan hasil penilaian dan evaluasi untuk kepentingan pembelajaran}

Hasil penelitian membuktikan bahwa kompetensi pedagogik tutor dalam proses pembelajaran di PKBM Citatah Endah ditinjau dari aspek pemanfaatan hasil penilaian dan evaluasi untuk kepentingan pembelajaran dilakukan dengan cara mengidentifikasi perkembangan peserta didik melalui kegiatan evaluasi pembelajaran dan menentukan beberapa tutor sebaya untuk pengembangan materi ajar. Keberhasilan pendidikan dapat dilihat dari kualitas proses belajar mengajar di kelas, yang secara langsung akan menunjukkan penguasaan manajemen pembelajaran oleh tutor sehingga menunjukkan pula prestasi belajar yang dicapai siswa. Hal ini penting, terutama dalam konteks profesionalisme tutor. Oleh karena itu, untuk 
memperlancar proses belajar perlu diperhatikan manajemen pembelajarannya, baik yang terdapat dalam diri tutor, warga belajar maupun yang ada di luar dirinya. Proses belajar mengajar merupakan inti dari proses pendidikan secara keseluruhan dengan tutor sebagai pemegang peranan utama. Proses belajar mengajar merupakan suatu proses yang mengandung serangkaian perbuatan dan tutor atas dasar hubungan timbal balik yang berlangsung dalam situasi edukatif untuk mencapai tujuan tertentu. Interaksi atau hubungan timbal balik antara tutor dan warga belajar merupakan syarat utama bagi proses belajar mengajar. Interaksi dan peristiwa belajar mempunyai arti yang lebih luas, tidak sekedar hubungan antara guru dan siswa, tetapi berupa interaksi edukatif.

Hal ini sesuai dengan pendapat Hamalik (2008) menyatakan bahwa pelajaran akan bermakna bagi siswa jika guru berusaha menghubungkannya dengan pengalaman masa lampau, atau pengalaman-pengalaman yang telah dimiliki sebelumnya. Adapun menurut Usman (2011) yang menyatakan bahwa pemberian penjelasan merupakan salah satu aspek yang amat penting dari kegiatan guru dalam interaksinya dengan siswa di dalam kelas, dan biasanya guru lebih mendominasi pembicaraan dan mempunyai pengaruh langsung, misalnya dalam memberikan fakta, ide, ataupun pendapat. Oleh karena itu, harus dibenahi keefektifannya agar tercapai hasil yang optimal dari penjelasan dan pembicaraan tersebut sehingga bermakna bagi murid. Deskripsi di atas menjelaskan bahwa suatu pembelajaran membutuhkan interaksi langsung antara siswa dengan gurunya. Pengajaran yang disampaikan guru hendaknya memiliki variasi metode yang dapat membangkitkan semangat peserta didik dalam proses belajar mengajar berlangsung di kelas.

\section{Pembahasan}

Hasil penelitian membuktikan bahwa kompetensi pedagogik tutor dalam meningkatkan motivasi belajar warga belajar di PKBM Citatah Endah dapat dilakukan dengan berbagai cara, yaitu:

\section{a) Memanfaatkan teknologi informasi dan komunikasi untuk kepentingan pembelajaran}

Hasil penelitian membuktikan bahwa kompetensi pedagogik tutor dalam meningkatkan motivasi belajar warga belajar di PKBM Citatah Endah ditinjau dari aspek pemanfaatan teknologi informasi dan komunikasi untuk kepentingan pembelajaran dilakukan dengan memberi kesempatan kepada peserta didik untuk terlibat aktif dalam menggunakan fasilitas teknologi informasi dan komunikasi dalam pencapaian tujuan pembelajaran. Komunikasi organisasi yang baik diharapkan dapat memberikan dukungan terhadap pencapaian tujuan organisasi, mengatur setiap peranan orang, kelompok, bagian dalam organisasi, memperjelas struktur hierarki formal organisasi, memperlancar interaksi-interaksi informal, dan lain-lain.

Oleh karena itu, Engkoswara dan Komariah (2011), menyebutkan bahwa efektivitas komunikasi organisasi ditentukan oleh: (a) struktur yang jelas untuk setiap fungsi dan peranan orang/bagian, (b) model komunikasi, dan (c) daya dukung teknologi yaitu kemampuan organisasi secara finansial dan sumber daya manusia. Keberhasilan sekolah dalam pencapaian tujuan pendidikan juga ditentukan oleh seberapa besar bahwa sekolah mampu menyerap pertumbuhan teknologi yang berkembang sesuai dengan kapasitasnya.

Teknologi yang dimaksud tidak hanya pendukung produksi atau jasa langsung, akan tetapi juga kaitannya dengan unsur komunikasi dalam organisasi yang harus difasilitasi dengan teknologi. Teknologi dalam komunikasi yang dimaksudkan adalah alat, teknik/cara yang dapat 
membantu tutor dalam menjalankan tugas mengajarnya. Sehubungan dengan penjelasan di atas, Engkoswara dan Komariah (2011), menyebutkan bahwa jenis-jenis teknologi dalam komunikasi organisasi dapat dikategorikan sebagai berikut: (a) teknologi dalam bentuk komunikasi tertulis, jenis ini terbagi dalam bentuk dokumen cetak dan dokumen elektronik. Penyusunan dokumen cetak dalam organisasi meliputi kegiatan-kegiatan perencanaan, penyusunan, revisi, produksi, dan distribusi. Adapun dokumen elektronik, bentuk penyusunannya dalam organisasi meliputi Local Area Network (LAN), Wide Area Network (WAN), dan internet, dan (b) teknologi dalam bentuk komunikasi lisan. Hal ini dapat dilakukan untuk individu seperti telepon, pager, voice mail, dan untuk kelompok meliputi telecoference, presentation, software, dan group decision support system.

Dari uraian tersebut, dapatlah dipahami bahwa pemanfaatan teknologi informasi dalam kebutuhan pembelajaran mutlak diperlukan untuk pengembangan kompetensi pedagogik guru dan peningkatan mutu peserta didik. Meskipun banyak juga permasalah-permasalahan yang muncul dari perkembangan teknologi informasi tersebut. Namun dalam menyikapi permasalahan yang muncul dari perkembangan teknologi informasi sebelumnya seorang guru dituntut harus memahami penggunaan dan prosedur cara kerja teknologi informasi tersebut.

\section{b) Berkomunikasi secara efektif, empatik, dan santun dengan peserta didik}

Hasil penelitian membuktikan bahwa kompetensi pedagogik tutor dalam meningkatkan motivasi belajar warga belajar di PKBM Citatah Endah ditinjau dari aspek berkomunikasi secara efektif, empatik, dan santun dengan peserta didik dilakukan setiap hari kerja dengan memberi sapaan dan teguran yang bersifat mendidik dan memperbaiki tingkah laku peserta didik. Komunikasi pada dasarnya adaah proses penyampaian pesan antara pengirim dan penerima.

Oleh karena itu, dalam suatu komunikasi akan terjadi apabila di dalamnya memiliki komunitor (orang yang menyampaikan informasi), komunikan (orang yang menerima informasi), pesan (sesuatu yang disampaikan baik berupa informasi, berita, perasaan, intruksi, keinginan, hasrat, dan sebagainya), media (bentuk atau cara informasi tersebut disampaikan. Media dapat berupa lisan, tulisan, gambar, video, musik dab bentuk lainnya), dan efek (perubahan yang terjadi pada komunikan sesuai dengan harapan komunikator). Aspek ini paling mendasari dalam suatu komunikasi yang efektif.

Komunikasi merupakan aktivitas dasar manusia. Dalam tinjauan manajemen, komunikasi diartikan sebagai salah satu kegiatan yang dilakukan untuk mengadakan hubungan antara manajer dengan bawahannya. Karena itu komunikasi perlu dilakukan agar maksud dan pesan yang disampaikan dapat diterima sesuai dengan keinginan pengirim berita. Engkoswara dan Komariah (2011), mengatakan bahwa komunikasi pemindahan makna/pemahaman dari pengirim kepada penerima, di dalam tercakup tiga bagian penting dari komunikasi yang efektif yaitu pengirim, penerima, dan keberhasilan pengiriman makna.

Adapun komunikasi dalam organisasi dipahami sebagai upaya untuk meniadakan kesenjangan sehingga pihak-pihak yang dilibatkan dalam proses komunikasi itu menjadi saling dekat satu dengan lainnya. Sehingga, hakikat komunikasi adalah saling mengakrabkan.

Dengan demikian jelaskan bahwa komunikasi adalah pemindahan informasi dan pemahaman dari satu orang ke orang lain. Komunikasi akan menjadi lebih efektif dan berkualitas apabila didukung oleh sikap percaya, menerima, empati, dan jujur di antara keduanya. Dari pengertian 
di atas, dapatlah diamati bahwa komunikasi adalah suatu kegiatan membuat orang lain mengerti apa yang dimaksud dalam proses komunikasi dilakukan. Dapat pula dipahami bahwa komunikasi adalah suatu saran pengalihan informasi dari komunikator kepada komunikan atau suatu sistem agar terbentuk jalinan komunikasi antar individu.

\section{c) Melakukan tindakan reflektif untuk peningkatan kualitas pembelajaran}

Hasil penelitian membuktikan bahwa kompetensi pedagogik tutor PKBM Citatah Endah dalam melakukan tindakan reflektif untuk peningkatan kualitas pembelajaran dilakukan dengan tes diagnostik untuk setiap materi pelajaran yang sudah diajarkan. Dalam tinjauan Djamarah (2010:320), yang dimaksud dengan tes diagnostik adalah tes yang dimaksudkan untuk mengetahui kesulitan belajar yang dialami siswa berdasarkan hasil tes formatif sebelumnya. Jadi dapat dipahami bahwa bentuk tindakan refleksasi yang diterapkan oleh guru adalah menguji sejauhmana kesulitan belajar yang dialami oleh peserta didik. Tes diagnostik memerlukan sejumlah soal untuk satu bidang yang diperkirakan merupakan kesulitan bagi siswa. Soal-soal tersebut bervariasi dan difokuskan pada kesulitan belajar.

Adapun kesulitan belajar dalam tinjauan Djamarah (2008) adalah suatu kondisi di mana anak didik tidak dapat belajar secara wajar, disebabkan adanya ancaman, hambatan ataupun gangguan dalam belajar. Tidak ada peserta didik yang tidak memiliki masalah dalam belajarnya, selain dari faktor intelegensi, kesulitan belajar peserta didik dapat disebabkan oleh beberapa indikator dengan sudut pandang mereka masing-masing.

\section{KESIMPULAN}

\section{Kesimpulan}

Dari hasil temuan penelitian, ada beberapa hal yang dapat penulis simpulkan antara lain: Kompetensi pedagogik tutor dalam perencanaan pembelajaran di PKBM Citatah Endah dilakukan dengan berpedoman pada kurikulum dan silabus. Dalam perencanaan pembelajaran tersebut memuat analisis materi pembelajaran yang di dalamnya memuat tentang standar kompetensi, kompetensi dasar, indikator dan materi pokok.

Kompetensi pedagogik tutor dalam proses pembelajaran di PKBM Citatah Endah dari sisi (a) penguasaan teori belajar dan prinsip-prinsip pembelajaran yang mendidik dilakukan dengan cara mendalami masing-masing materi pembelajaran secara konseptual melalui bacaan bukubuku dan literatur tentang disiplin ilmu masing-masing, (b) pengembangan kurikulum yang terkait dengan mata pelajaran yang diampu dilakukan dengan memantapkan sejumlah materi pembelajaran kepada siswa secara baik dan benar dan sesuai alokasi waktu pembelajaran yang disediakan, (c) pengembangan potensi peserta didik untuk mengaktualisasikan berbagai potensi yang dimiliki dilakukan dengan memberikan sejumlah latihan dalam bentuk pekerjaan rumah yang berhubungan dengan materi pembelajaran yang sudah diajarkan, dan (d) memanfaatkan hasil penilaian dan evaluasi untuk kepentingan pembelajaran dilakukan dengan cara mengidentifikasi perkembangan peserta didik melalui kegiatan evaluasi pembelajaran dan menentukan beberapa tutor sebaya untuk pengembangan materi ajar.

Kompetensi pedagogik tutor dalam meningkatkan motivasi belajar warga belajar di PKBM Citatah Endah dapat dilakukan dengan berbagai cara, yaitu: (a) memanfaatkan teknologi

informasi dan komunikasi untuk kepentingan pembelajaran dilakukan dengan memberi 
kesempatan kepada peserta didik untuk terlibat aktif dalam menggunakan fasilitas teknologi informasi dan komunikasi dalam pencapaian tujuan pembelajaran, (b) berkomunikasi secara efektif, empatik, dan santun dengan peserta didik dilakukan setiap hari kerja dengan memberi sapaan dan teguran yang bersifat mendidik dan memperbaiki tingkah laku peserta didik, dan (c) melakukan tindakan reflektif untuk peningkatan kualitas pembelajaran dilakukan dengan tes diagnostik untuk setiap materi pelajaran yang sudah diajarkan.

\section{Saran}

Adapun saran-saran yang diajukan terkait pembahasan yang terkait dengan penelitian ini adalah sebagai berikut:

a. Pengelola PKBM Citatah Endah memiliki kesempatan untuk melakukan sosialisasi desain sistem instruksional untuk meningkatkan kemampuan dan pemahaman tutor terhadap kegiatan merencanakan dan pengelolaan pembelajaran;

b. Dalam aspek strategi pembelajaran, kepala PKBM hendaknya dapat bertindak tegas dalam mengambil suatu kebijaksanaan terhadap kedisiplinan guru dan hal-hal lain yang berkenaan dengan proses belajar mengajar, begitu pula sebaliknya para tutor PKBM Citatah Endah diharapkan untuk meningkatkan kedisiplinan dalam mengajar dengan memperbanyak penggunaan metode dan media pembelajaran saat proses belajar mengajar berlangsung.

c. Dalam kajian evaluasi pembelajaran, para tutor PKBM Citatah Endah, diharapkan dapat meningkatkan kemampuan didaktik dan metodik dalam pembelajaran. Dengan pemahaman ilmu didaktik-metodik secara mendalam dapat memudahkan guru dalam pengelolaan evaluasi pembelajaran sehingga memotivasi dan semangat belajar siswa dapat ditingkatkan.

d. Dalam konteks manajemen pembelajaran, ketua MGMP hendaknya memahami pengelolaan pembelajaran yang menyangkut dengan aspek perencanaan, penerapanan strategi belajar mengajar, dan evaluasi pembelajaran yang sudah diterapkan oleh para tutor PKBM Citatah Endah, selanjutnya membuat laporan kemajuan kegiatan dan dilaporkan kepada kepala PKBM.

\section{DAFTAR PUSTAKA}

Djamarah, S. B., 2011. Psikologi Belajar. Jakarta: Rineka Cipta.

-, 2010. Guru Dan Anak Didik dalam Interaksi Edukatif. Jakarta: Rineka Cipta. -, 2008. Prestasi Belajar dan Kompetensi Guru. Surabaya: Usaha Nasional.

Engkoswara dan Aan Komariah, 2011. Administrasi Pendidikan. Bandung: Alfabeta.

Hamalik, O., 2012. Kurikulum dan Pembelajaran. Jakarta: Bumi Aksara. 2008. Proses Belajar Mengajar. Jakarta: Bumi Aksara.

Harun, C. Z., 2010. Manajemen Sumber Daya Pendidikan. Yogyakarta: Pena Persada.

Margono, S., 2010. Metode Penelitian Pendidikan. Jakarta: Rineka Cipta.

Mulyasa, E., 2009. Standar Kompetensi dan Sertifikasi Guru. Bandung: Remaja Rosdakarya. 
Sagala, S., 2012. Konsep dan Makna Pembelajaran Untuk Membantu Memecahkan Problemetika Belajar dan Mengajar. Bandung: Alfabeta.

Sudjana dan Ibrahim, 2010. Penelitian dan Penilaian Pendidikan. Bandung: Sinar Baru Algesindo.

Sudjana, N., 2011. Dasar-Dasar Proses Belajar Mengajar. Bandung: Sinar Baru Algesindo.

Sugiyono, 2012. Metode Penelitian Pendidikan: Pendekatan Kuantitatif, Kualitatif, dan R\&D. Bandung: Alfabeta.

Uno, H. B., 2009. Profesi Keguruan, Problema, Solusi, dan Reformasi Pendidikan di Indonesia. Jakarta: Bumi Aksara.

Usman, U., 2011. Menjadi Guru Profesional. Bandung: Remaja Rosdakarya. 